\title{
Solar panels work and control system modeling in LabVIEW and LTSpice XVII. Comparison of the perspectives of panels using
}

\author{
O. Drozd $d^{\bowtie}$, L. Scherbak ${ }^{2}$ \\ ${ }^{1,2}$ Kyiv International University, 49, Lvivska str., Kyiv, 03179, Ukraine \\ $\triangle$ e-mail:: ${ }^{1}$ mrme9093@gmail.com
}

This paper is dedicated to the research of solar energy issues, namely to increase the efficiency of solar panels and to compare the performance of solar panels in different configurations. The author researches and compares the performance of solar panels with and without trackers. The sun is an inexhaustible source of energy that mankind has yet to appreciate. Solar energy is the kinetic energy of radiation (mainly light) generated by thermonuclear reactions in the bowels of the sun. Solar energy is one such alternative, the neglect of which will in the near future lead to catastrophic consequences for humanity. Solar energy is a progressive method of obtaining various types of energy through solar radiation. Solar energy is one of the most promising and dynamic renewable energy sources (RES). Each year, the increase in commissioned capacity is approximately 40-50\%. In the last fifteen years alone, the proportion of solar electricity in the world has exceeded the 5\% mark. To increase the efficiency of solar panels, designers and engineers are developing new devices and devices, one of which is a solar tracker. A solar tracker is a device that allows you to control the movement of the sun across the sky, as well as move the solar panel to the position where the absorption of sunlight is most effective. After the conducted experiment, calculations an comparison we can see the next results. Without the solar tracker our panel generated maximum power in 2.4 Watt. After the solar tracking system integration, our panel generated almost 20 (19.8) Watt of power! After this comparison we can tell that the generated power increase in 8.25 Watts. We can also admit that the amount of generated power depends on light intensity. But solar panels are the most effective when the solar beam falls perpendicular to solar cell and solar panel is at an angle of $75-85$ degrees.

Keywords: Solar energy; Prospects; Solar tracker; Electrical circuit; Comparison; Model

doi: https://doi.org/10.15673/ret.v57i1.1977

(C) The Author(s) 2021. This article is an open access publication

This work is licensed under the Creative Commons Attribution 4.0 International License (CC BY)

http://creativecommons.org/licenses/by/4.0/

\section{Introduction}

Solar energy is one of the most promising and dynamic renewable energy sources (RES). Each year, the capacity increase put into operation is approximately $40-50 \%$. In just the last fifteen years, the share of solar electricity in the world has exceeded the 5\% mark. Improvement in the technology of manufacturing photovoltaic modules has led to a significant reduction in the cost of electricity. In more than 30 countries (including Germany, Chile, Australia, Mexico), solar energy has become cheaper than traditional sources (oil, gas, coal). Over the past 10 years, investments in solar energy have amounted to about $\$ 300$ billion. The most illustrative example of the success of solar technology is Tau Island (American Samoa). Previously, the islanders were completely dependent on diesel supplies.

Ukraine is taking important steps to increase the 
use of RES and alternative fuels as part of its broader strategy to reduce dependence on traditional fossil fuels. It is estimated that our country has the potential to increase tenfold renewable energy by 1030 and reduce natural gas consumption by $15 \%$.

It is worth noting that the climate and geographical location of Ukraine are favorable for the development of solar energy and the construction of SES. Even the northern regions of the country have considerable potential for the development of this industry, which is not inferior to most European regions.

Currently, the development of solar energy in Ukraine is at a stage that Europe has undergone 7-10 years ago. At the same time, we have one of the most attractive investment structures in Europe for the development of the industry. Indeed, favorable conditions have been created here: availability of resources and land, a preferential tariff, state support and a targeted energy strategy that aims to reach $25 \%$ of clean energy production by 2035 . As a result, interest in renewable energy in Ukraine continues to grow, and the government estimates that by 2020 , total investment in alternative energy will reach $\$ 18$ billion.

Although the RES sector is still small in comparison to other types of generation in Ukraine, it is still showing steady growth, making our country a leader in this sector. From 2014 to the end of 2017, the volume of RES increased from 967 to $1375 \mathrm{MW}$ and by the end of $Q_{1} 2018$ to $1534 \mathrm{MW}$ (Fig. 1).

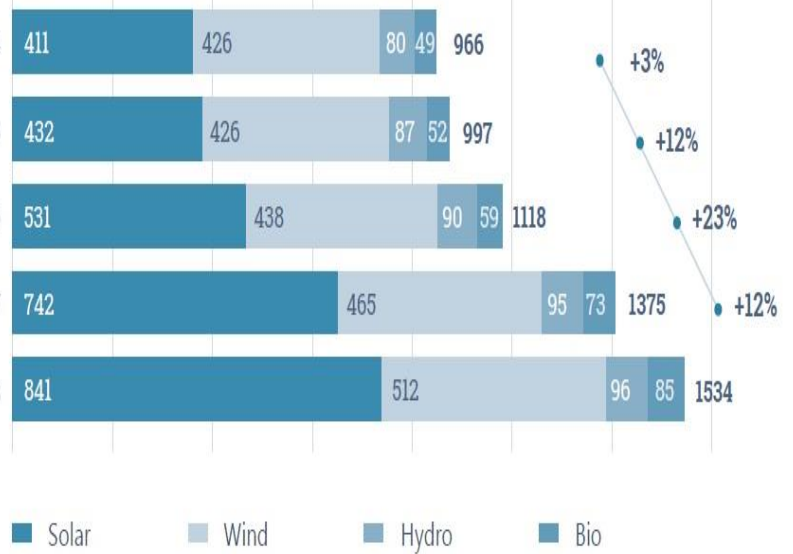

Figure 1 - RES growth for 2014 - I quarter of 2018

How exactly renewable energy sources are distributed by region and what type of RES prevails in a given region can be seen in Fig. 2.

Since solar energy is a very popular RES in Ukraine, it can be observed that the regional distribution of installed RES correlates with the level of inso- lation. The focus is on the regions with the highest solar activity, as shown in the map below (Fig. 3).

The question about solar battery performance is one of the first to be asked by people planning to invest in a solar power plant.

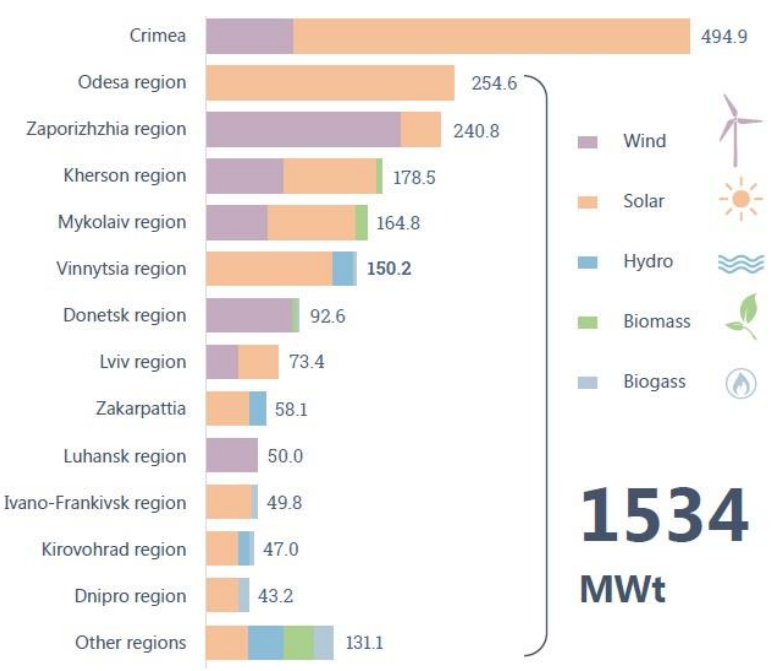

Figure 2 - Production of RES by regions
as of $Q_{1} 2018$

The amount of electricity that will be produced by the solar module depends on many factors, including the geographical location of the solar power plant. For all other things being equal, the amount of electricity generated will be proportional to the amount of solar radiation reaching the surface of the earth at the location of the power plant.

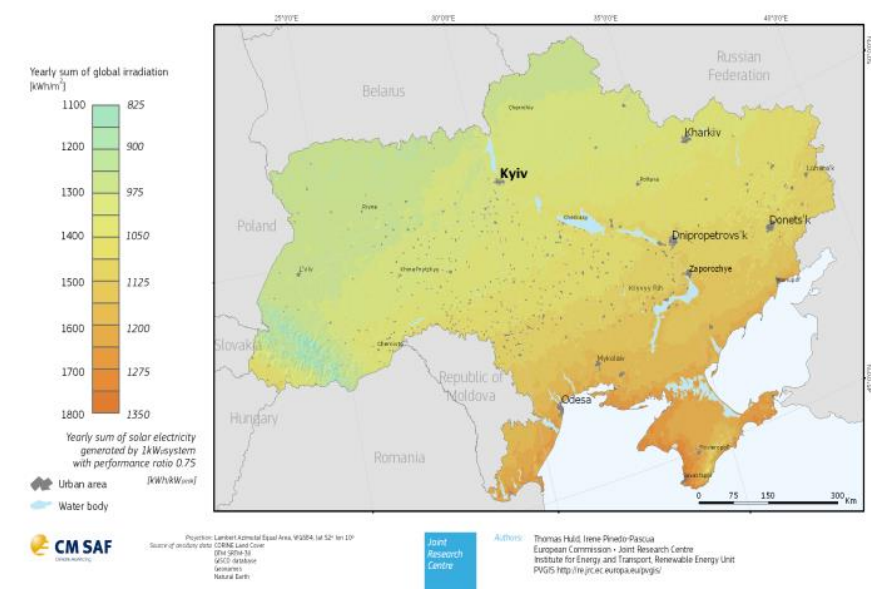

Figure 3 - Radiation and solar energy potential in Ukraine

Solar energy is one of the environmentally sustainable resources for the production of electricity using photovoltaic (PV) systems - solar power plants. The primary source of data used in the planning process is solar radiation. The Photovoltaic Geographic 
Information System (PVGIS) of the Joint Research Institute (IRS) of the Joint Research Institute (JRS) of the European Commission (EC) has developed a database on solar radiation. The model estimates the radiation, diffuse and reflected components of the radiation in clear weather and for real global illumination on horizontal or inclined surfaces.

The summarized results of the simulation are periodically published maps of solar electric potential, available for use by anyone. The information published by PVGIS is quite detailed. Above is a visualization of the most current data on solar potential in Ukraine and European countries. The information was updated on September 21, 2012. This map shows the distribution of global solar irradiation and solar electric potential in the territory of Ukraine for the orientation of solar modules to the south at an optimal angle of inclination relative to the earth's surface (maximum perpendicular angle of incidence of sunlight to the surface of the solar battery). For comparison, we also offer a map of the solar potential for Europe:

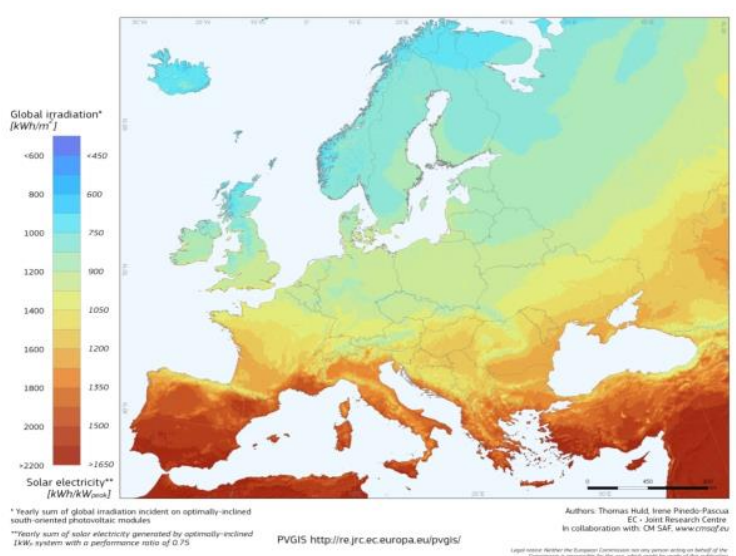

Figure 4-Solar potential for Europe

It is projected that by 2020 the capacity of installed solar energy facilities in Ukraine will increase to $3 \mathrm{GW}$. As of April 1, 2019, more than 2,2 GW of solar energy facilities have been installed in the country, accounting for $71 \%$ of all existing RES. Such rapid and active development of the industry has allowed Ukraine to rise from 34th to 23rd place in the global solar energy rating.

In the future, Ukraine can take on the successful experience of our foreign counterparts to expand the prospects for solar energy.

Everybody knows and even saw many modern electric cars on the roads of our country's metropolises, but few people know that in European countries photovoltaic cells are placed on the roofs of trains and provide them with electricity during operation. In the long term, this technology can be applied to both water and aircraft.

Thermal energy is a way of converting the energy of the sun through the heating of water in containers made of materials that conduct heat well.

In general, solar power will increase capacity in Ukraine because:

- is the interest of foreign investors;

- in many countries where the SES equipment is operating as efficiently as possible;

- a one-time investment guarantees long-term profit.

Why is it promising to build solar power plants? In our vision solar energy and energy conservation are a worldwide trend. 2017 has been a landmark year for solar photovoltaics - the world's largest solar power plant has been commissioned compared to other types of power generation technology. The five largest national markets - China, USA, India, Japan and Turkey - account for almost $84 \%$ of the newly installed capacity. This is followed by Germany, Australia, Republic of Korea, United Kingdom and Brazil. China, the USA, Japan, Germany, Italy and India are leading in aggregate capacity (Fig. 5-6).

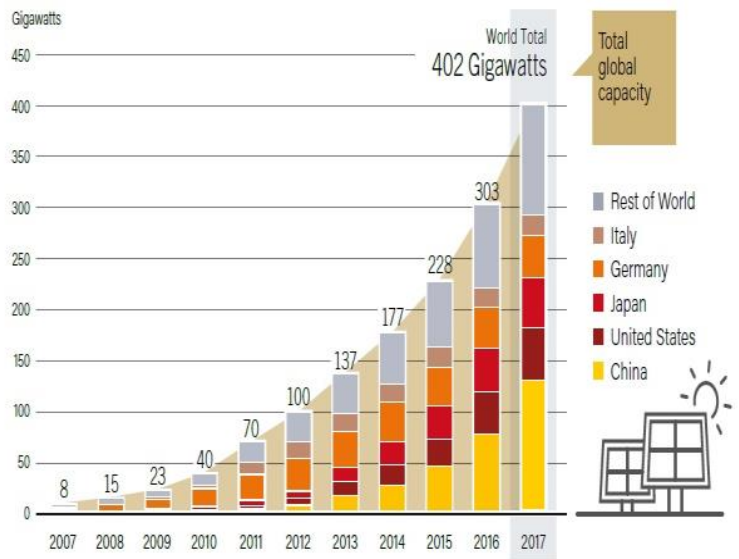

Figure 5 - Global capacity of solar photovoltaic systems by country or region, 2007-2017

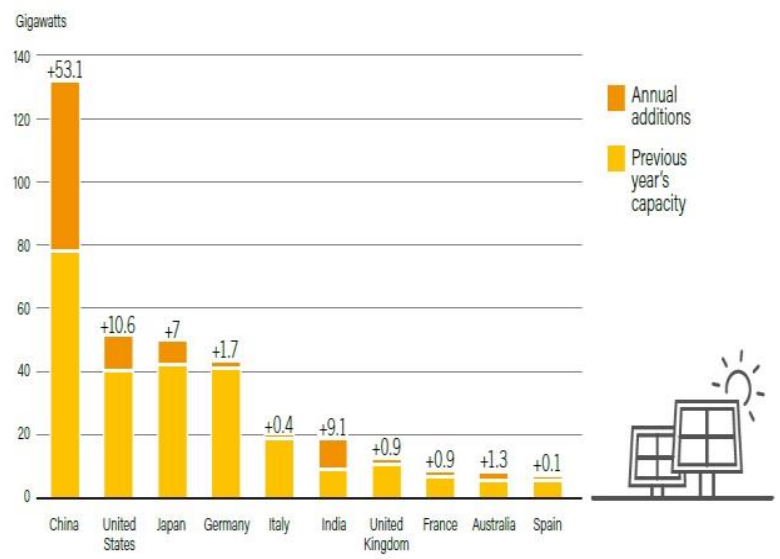

Figure 6 - Top 10 Solar Energy Capacity and Growth Countries, 2017 
A very illustrative example of the development of solar technologies is China, which has become the world leader in the power of solar power plants in just five years with the market outsiders. During 20162020, China is investing about $\$ 145$ billion in the construction of the SES - this will enable the commissioning of about 1,000 powerful SES. China has long been a leader in the solar panel and hardware industry. China controls $70 \%$ of the world's solar panels and is leading the way in solar usage. It is projected that by 2040 China will provide $28 \%$ of all investment in electricity generation.

According to experts, already by 2070 , solar energy will be the main source of electricity on Earth, and by the beginning of the next century, solar energy will be 3,5 times higher than the oil industry and 6 times the nuclear power. Solar energy is virtually inexhaustible, and is also a completely free resource.

Modern technologies allow to receive solar panels which at the minimum operating expenses and maintenance will provide efficient generation of electricity for at least 30 years.

Analysts predict that between 2017 and 2022 global solar prices will decline by an average of $27 \%$. Utility-scale solar installations will cost less than coalfired power plants in all developed countries. Indeed, in many places in the world (including some in the US), solar energy has already reached parity, ie the cost of solar energy is equal to or lower than the cost of purchasing energy from the grid.

Favorable climate - the level of insolation (that is, the amount of solar radiation per square meter of the Earth's surface) in most regions of Ukraine exceeds similar indicators of Germany, which is one of the world leaders in the field of solar energy.

A favorable legal framework that really stimulates investment in alternative energy is the green tariff at which the state purchases all electricity produced by the SES - one of the highest in Europe. In April 2019, a law on green auctions was approved. According to him, participation in the auctions will be mandatory from 2020 for solar power projects with capacity exceeding $1 \mathrm{MW}$ and wind power plants with capacity exceeding $5 \mathrm{MW}$. Under the terms of the auction, the one who offers the lowest price will be able to sell "clean" electricity to the state. The auction is designed to prevent monopoly in the Ukrainian RES market. This should be a transparent competition held through the ProZorro e-commerce system twice a year, in the fall and spring.

Opportunities to invest in Ukraine's alternative energy sector are extremely favorable, as the country has a diverse supply of raw materials and a welleducated workforce that has the technical know-how needed to develop and implement the latest commercial developments in the sector.

The constant rise in the cost of electricity makes it justified to invest in generating its own electricity. Speaking of cost, we can already talk about price parity between alternative and traditional electricity.

The energy independence of production (business) and the formation of a positive image of an innovative, socially responsible company in the eyes of society and potential customers.

The payback period of investments, depending on the type and capacity of the SES, is 5-7 years, for private (domestic) solar power plants - up to 10 years.

Low Maintenance Costs - minimum number of maintenance staff due to high automation and low maintenance costs.

Reduced operating costs / energy savings - the solar energy system can reduce or even eliminate the electricity bill for your business.

Technology development - technology in the solar industry is constantly evolving, and in the future improvements will be accelerated. Innovations in quantum physics and nanotechnology can potentially increase the efficiency of solar panels and double or even triple the electrical power of solar energy systems.

Avenston is one of the leaders of solar energy in Ukraine and a recognized expert in the field of design and construction of solar power plants. Our company has extensive practical experience and offers collaboration in turnkey project management in the RES field. This means that we will provide consulting and complete service for the construction and maintenance of solar power facilities, including technical, financial, legal and formal aspects.

In order to increase the efficiency of using solar panels, designers and engineers are developing new devices and devices, one of which is a solar tracker.

The solar tracker is a device that allows you to monitor the movement of the sun across the sky, and move the solar panel to a position in which the absorption of sunlight is most effective.

The advantages of installing a tracker can be formulated as follows:

The efficiency of solar panels increases by 40 $45 \%$. The increase is achieved due to the fact that the most effective operation of the panels occurs when the sun's rays fall at an angle of 90 on the solar cells of 
the panel; Due to the installation of the tracker, the efficiency of solar panels increases significantly, the amount of generated electrical energy increases. Due to the increase in productivity of a single panel, there is no need to install additional panels, which in turn reduces the cost of the entire set of solar power plants.

\section{Modeling of solar panel with LTSpice XVII}

Basically the electronic circuit of solar panel can be modeled as follows:

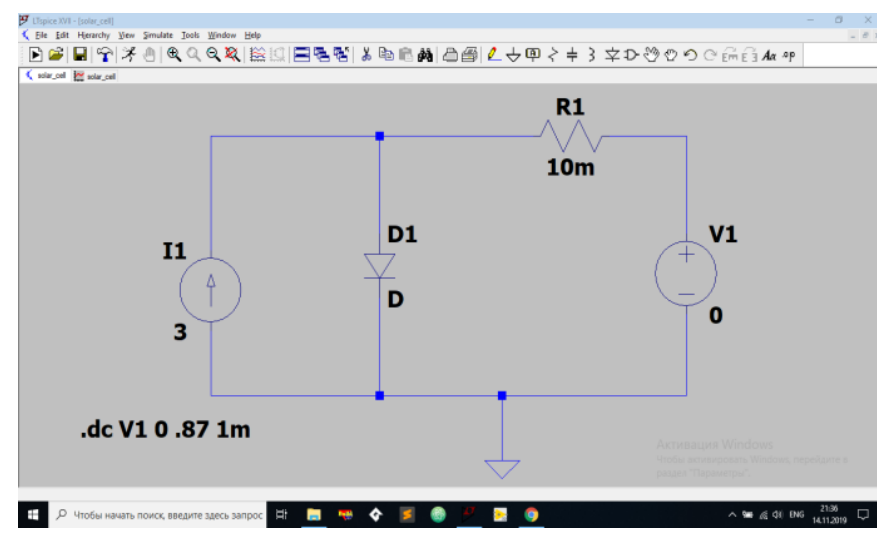

As we can see, it consist of:

- Current source

- Diode
- Resistor (only one taken for simulation simplicity)

- Voltage Meter

For now it there is no solar tracker here. We'll model it a bit later.

Now let's see how our solar panel behaves.

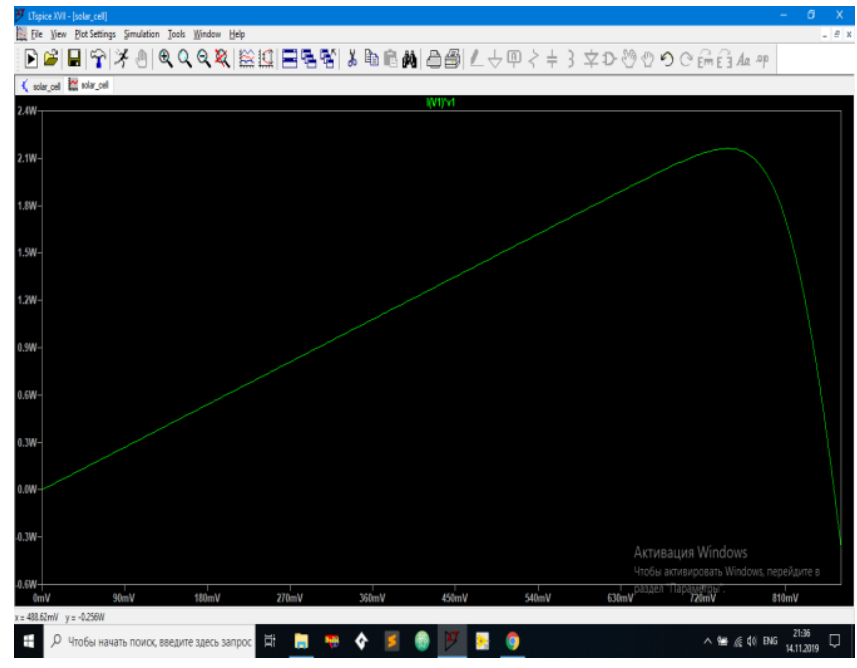

As we can see, our solar panel generates power of 2,1-2,4 W without solar tracker. Now let's get in LabVIEW 2019 and simulate solar tracker control system there and see the results.

Here is the GUI of the system:

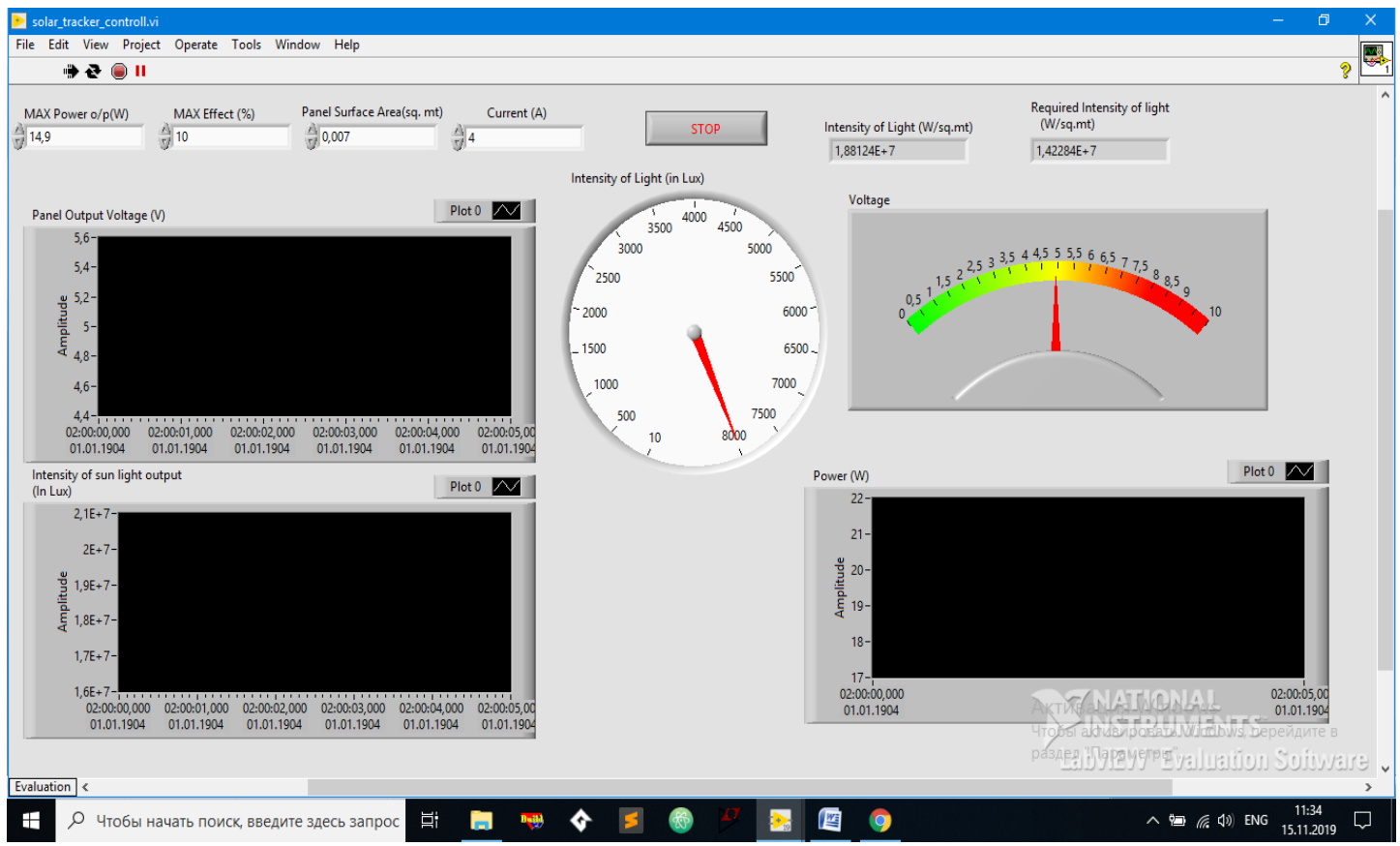

And the source code: 


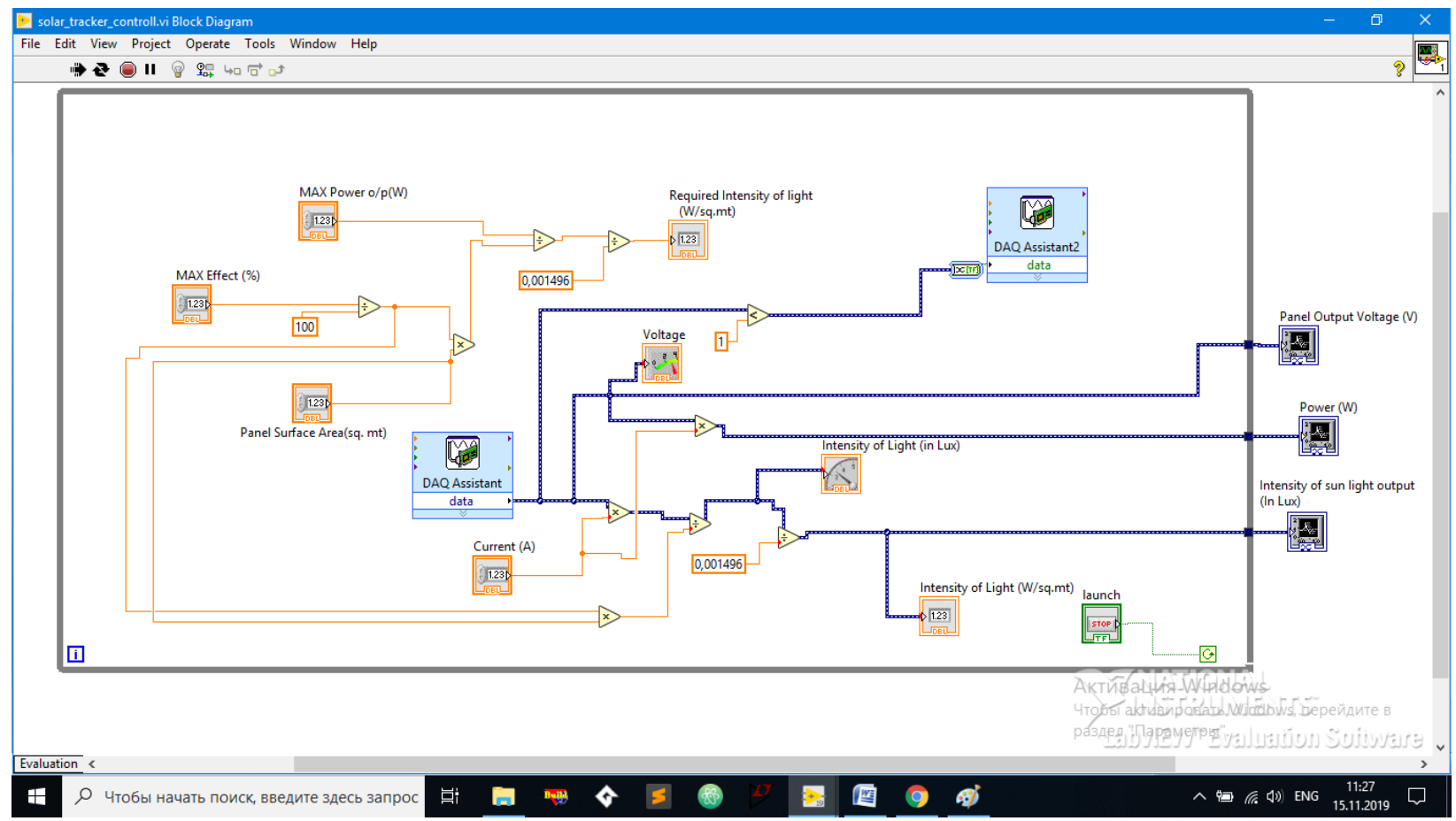

Now let's start the simulation and see how the system behaves:

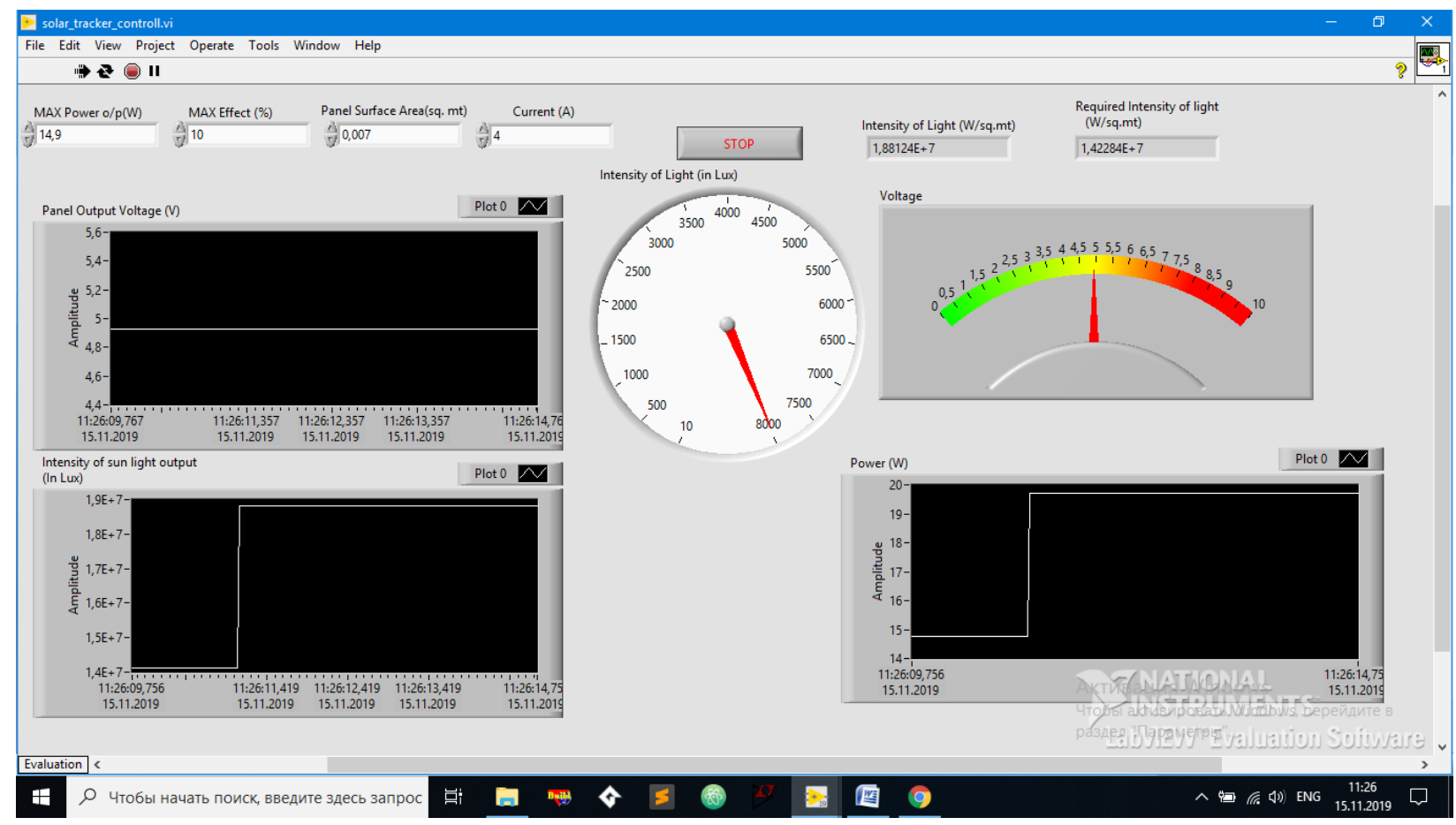

As we can see, the system analyzes the intensity of light and generated power in accordance with it. So with sun tracker our panel almost $20(19,8)$ Watt of power instead of 2,4 Watt. It's 8,25 Watts more!

The calculations of solar panel power:

$$
P=I \cdot V, \mathrm{~W}
$$

Maximum efficiency of solar panel

$$
\eta_{\max }=j \cdot s
$$

where $j$ - incident radiation flux $\left(\mathrm{W} / \mathrm{m}^{2}\right) ; s$ - area of collector $\left(\mathrm{m}^{2}\right)$.

But we know that: $1 \mathrm{Lux}=0,001496\left(\mathrm{~W} / \mathrm{m}^{2}\right)$. Incident radiation 


$$
J=0,001496 \cdot j \cdot S
$$

From equation (3) we can get the intensity of light (in lux) with help of input voltage.

After the conducted experiment, calculations an comparison we can see the next results. Without the solar tracker our panel generated maximum power in 2,4 Watt.

After the solar tracking system integration, our panel generated almost $20(19,8)$ Watt of power! After this comparison we can tell that the generated power increase in 8,25 Watts. We can also admit that the amount of generated power depends on light intensity (we can see it from equation 1). But solar panels are the most effective when the solar beam falls perpendicular to solar cell and solar panel is at an angle of 75-85 degrees.

\section{Conclusion}

In our opinion, solar energy is one of the most promising and dynamic renewable energy sources (RES). According to the authors, solar panels are the most efficient and environmentally friendly way to generate electricity. The most effective are solar panels with single crystalline photocells (15-19\%). But with solar trackers they become much more efficient and produce more energy. This allows us to install fewer solar panels, which in turn reduces the cost of the entire solar power plant. The efficiency of solar panels increases by $40-45 \%$. In Ukraine, energy generation gains are led by Kyiv (36,7\%), Kherson (34\%) and Chernihiv (34,6\%). The increase is achieved by the fact that the most efficient operation of the panels occurs when the sun's rays fall at an angle of 90 on the solar cells. In our case, the amount of power generated increased almost 9 times. This testifies to the prospects of this technology both today and in the future, as technology is constantly evolving and improving.

\section{CRediT author statement}

Oleksii Drozd: methodology, modeling, programming, writing - original draft. Leonid Scherbak: conceptualization, curation, methodology, writing - review \& editing, supervision.

\section{References}

1. Misak, J. S., Wozniak, O. T., Datsko, O. S., Shapoval, S.P. (2014) Solar energy: theory and practice: monograph. Lviv: Lviv Polytechnic Publishing House, 340.

2. Alferov, Zh. I., Andreev, V. M., Rumyantsev, V. D. (2004) Trends and prospects for the development of solar photoenergy. Physics and technology of semiconductors, 38(8), 937-948.

3. McWeig, D. (2011) The use of solar energy. Moscow: Energoizdat, 210.

4. Umarov, G. Ya., Ershov, A. A. (2014) Solar energy. Moscow: Znanie, 64.

5. Alekseev, V. V., Chekarev, K. V. (2017) Solar energy. Moscow: Znanie, 74.

Received 31 January 2021

Approved 08 February 2021

Available in Internet 11 February 2021

\title{
Моделювання системи управління сонячними панелями в LabView та LTSpice. Порівняння ефективності сонячних панелей на трекерах і без них
}

\author{
О. Дрозд ${ }^{1 \bowtie}$, Л. Щербак ${ }^{2}$ \\ 1,2Київський міжнародний університет, вул. Львівська, 49, Київ, 03179, Україна \\ $\triangle$ e-mail:: ${ }^{1}$ mrme9093@gmail.com
}

Ця стаття присвячена дослідженню питань сонячної енергетики, а саме підвищенню ефективності використання сонячних панелей та порівнянню характеристик сонячних панелей у різних конфігурачіях. Автор досліджує та порівнює характеристики сонячних панелей з трекерами та без них. Сонце - невичерпне джерело енергії, яке людство ще не оцінило. Сонячна енергія - ие кінетична енергія випромінювання (головним чином світла), що генерується термоядерними реакціями в надрах Сония. Сонячна енергія - одна з таких альтернатив, нехтування якою най- 
ближчим часом призведе до катастрофічних наслідків для людства. Сонячна енергія - че прогресивний метод отримання різних видів енергї за допомогою сонячного випромінювання. Сонячна енергія є одним з найбільш перспективних та динамічних відновлюваних джерел енергіі (ВДЕ). Щороку приріст введених в експлуатацію потужностей становить приблизно 40-50\%. Лише за останні п'ятнадиять років частка сонячної електроенергї̈ у світі перевищила позначку 5\%. Для підвищення ефективності використання сонячних панелей дизайнери та інженери розробляють нове обладнання та пристрої, одним з яких є сонячний трекер. Сонячний трекер це пристрій, щзо дозволяє контролювати рух сония по небу, а також пересувати сонячну панель у положення, де поглинання сонячного світла $\epsilon$ найбільш ефективним. Після проведеного експерименту, обчислень, порівняння ми можемо побачити наступні результати. Без сонячного трекера нама панель генерувала максимальну потужність в 2,4 Вm. Після інтеграчії сонячної системи відстеження наша панель генерувала майже 20 (19,8) Вт потужності! Після иьього порівняння можна сказати, що генерована потужність збільшується на 8,25 Вт. Ми також можемо визнати, щуо кількість генерованої потужності залежить від інтенсивності світла. Але сонячні панелі є найбільш ефективними, коли сонячний промінь падає перпендикулярно сонячній батареї, а сонячна панель знаходиться під кутом 75-85 градусів.

Ключові слова: Сонячна енергія; Перспективи; Сонячний трекер; Електрична схема; Порівняння; Модель

\section{Література}

1. Мисак Й.С., Возняк О.Т., Дацько О.С., Шаповал С.П. Сонячна енергетика: теорія та практика: монографія. - Львів: Вид-во Львівської політехніки, 2014. - $340 \mathrm{c}$.

2. Алфёров Ж. И., Андреев В. М., Румянцев В. Д. Тенденции и перспективы развития солнечной фотоэнергетики // Физика и техника полупроводни- ков. - 2004. - Т. 38. - Вып.8. - С. 937-948.

3. Мак-Вейг Д. Применение солнечной энергии. М.: Энергоиздат, 2011. - 210 с.

4. Умаров Г. Я., Ершов А. А. Солнечная энергетика. - М.: Знание, 2014. - 64 с.

5. Алексеев В. В., Чекарев К. В. Солнечная энергетика. - М.: Знание, 2017. - 74 с.

Отримана в редакції 31.01.2021, прийнята до друку 08.02.2021 